\title{
Ecological correlates of odonate assemblages of a Mediterranean stream, Wadi Cherf, northeastern Algeria: implications for conservation
}

\author{
Zineb Bouhala ${ }^{\mathrm{a}, \mathrm{b}}$, Chakri Khemissa ${ }^{\mathrm{a}, \mathrm{b}}$, Joaquín Márquez-Rodríguez ${ }^{\mathrm{c}}$, Manuel \\ Ferreras-Romero $^{\mathrm{c}}$, Farrah Samraoui (D) ${ }^{\mathrm{a}, \mathrm{d}}$ and Boudjéma Samraoui (iD) ${ }^{\mathrm{a}, \mathrm{b} *}$ \\ ${ }^{a}$ Laboratoire de Conservation des Zones Humides, Université 8 Mai 1945 Guelma, Guelma, Algeria; \\ ${ }^{b}$ Départment of Biology, University of Annaba, Annaba, Algeria; ${ }^{c}$ Department of Physical, Chemical and \\ Natural Systems, University Pablo de Olavide, Seville, Spain; ${ }^{d}$ Department of Ecology, Université 8 Mai \\ 1945 Guelma, Guelma, Algeria
}

(Received 17 August 2019; accepted 30 October 2019)

\begin{abstract}
We investigated the odonates of Wadi Cherf, a tributary of Wadi Seybouse, and explored the main environmental factors that may be important drivers of the abundance and diversity of Odonata assemblages. PCA analyses demonstrated a significant altitudinal gradient associated with water flow, temperature, vegetation cover, substrate and adjacent land use. Notably, pollution was a dominant structuring factor and the most widespread species, Ischnura graellsii and the North African endemic Platycnemis subdilatata, were the most pollution-tolerant species. Similarly, co-inertia analysis indicated that environmental factors could account for $70 \%$ of the co-variation in shaping odonate assemblages. Equally important, threatened species were associated with less degraded but vulnerable habitats, most susceptible to anthropogenic impacts. There is thus a need to develop monitoring tools to assess the ecological integrity of North African rivers and implement a management plan that considers both connectivity and heterogeneity to ensure that Wadi Cherf, a sanctuary to three threatened species Calopteryx exul (EN), Coenagrion mercuriale (EN) and Gomphus lucasii (VU), continues to provide critical ecosystem functions.
\end{abstract}

Keywords: anthropogenic stressors; conservation; distribution; freshwater biodiversity; global change; river; Odonata; dragonfly

\section{Introduction}

The complex life cycles of Odonata link aquatic and terrestrial communities (Corbet, 1999; Remsburg \& Turner, 2009) and their ecological requirements have made them key indicator species of the quality of freshwater ecosystems and the management of aquatic biodiversity (Bried \& Samways 2015; Samways, McGeoch \& New, 2010). Knowledge of these ecological requirements has been turned into a useful tool for the evaluation of the overall conservation status of aquatic environments and wetland bio-monitoring (Steward \& Downing, 2008).

In the last two decades, considerable attention has been devoted to increasing our knowledge of the distribution of Algerian odonates (Boudot et al., 2009; Samraoui \& Corbet, 2000a; Samraoui \& Menai, 1999). Yet, despite numerous studies, the size of the Algerian territory has made

*Corresponding author. Email: bsamraoui@gmail.com 
it difficult to access many localities, so previous surveys have generally been confined to accessible sites. Such investigations, though useful, are biased and incomplete as relatively pristine habitats may have been left out of such surveys.

This is the case for the River Seybouse where previous studies of the main affluent, Wadi Cherf, have only been carried out in a small number of sites (Khelifa et al., 2011; Yalles-Satha \& Samraoui, 2017). Thus, little is known about the odonates of the upper reaches of the River Seybouse. In addition, these past studies now date back about one decade.

Such a gap in our knowledge has implications for conservation, as the Upper Seybouse is the only known sanctuary for the Endangered Calopteryx exul, a Maghrebian endemic (YallesSatha \& Samraoui, 2017). Indeed, following the first global assessment of Odonata (Clausnitzer et al., 2009), great efforts have been devoted to assessing the status of North African (Samraoui et al., 2010) and Mediterranean odonates (Riservato et al., 2009) but, as multiple anthropogenic stressors like land conversion, pollution and climate change are fast affecting the North African riverine landscape (Hafiane et al., 2016; Morghad, Samraoui, Touati, \& Samraoui, 2019), there is an urgency to continually update our knowledge.

Understanding how ecological processes shape odonate assemblages by disentangling the relative influence of biotic and abiotic factors may provide insights into how freshwater communities will respond to ongoing and future disturbances like pollution, climate change and invasive species (Hofmann \& Mason, 2005; Rahel \& Olden, 2008; Weiher \& Keddy, 1999). This paper aims to provide a comprehensive account of the composition and distribution of odonate assemblages of Wadi Cherf and explore how environmental (essentially abiotic) factors drive their diversity and abundance. Another objective of the study is to evaluate how threatened species respond to environmental factors and identify potential threats to their habitats.

\section{Materials and methods}

\section{Study area}

Intermittent rivers and streams are known, throughout North Africa and the Middle East, as wadis. Wadi Cherf, located in the northeastern part of Algeria, occupies a surface of 2905 $\mathrm{km}^{2}$. It borders three districts (wilayas): Souk Ahras, Guelma and Oum El Bouaghi (Figure 1) and constitutes the upper course of the River Seybouse. Wadi Cherf originates in the eastern Hauts Plateaux at an altitude that varies from $800 \mathrm{~m}$ to $1000 \mathrm{~m}$. The climate is typically Mediterranean, divided into a rainy season from October to May and a dry season from June to September. Rainfall ranges from $350 \mathrm{~mm} /$ year upstream to $610 \mathrm{~mm} /$ year downstream. Contrary to the downstream part of the River Seybouse, there are no industrial plants in the watershed of Wadi Cherf. However, points of discharge of untreated sewage are often present near agglomerations, and wadis are commonly used as drinking water sources for grazing livestock.

\section{Sampling}

Monthly sampling was carried out at 22 localities (S1-S22) over a three-year period from 30 July 2014 to 27 June 2017 and totaling 580 samples. At each locality, adult Odonata were sampled by walking slowly and repeatedly along a $50 \mathrm{~m}$ transect. Flying adults, often identified to species on sight, were collected using an insect net. These voucher specimens were identified and kept in the laboratory. Odonata have complex life histories that link aquatic and terrestrial communities (Remsburg \& Turner, 2009). Adults and larvae display congruent distributional patterns and 


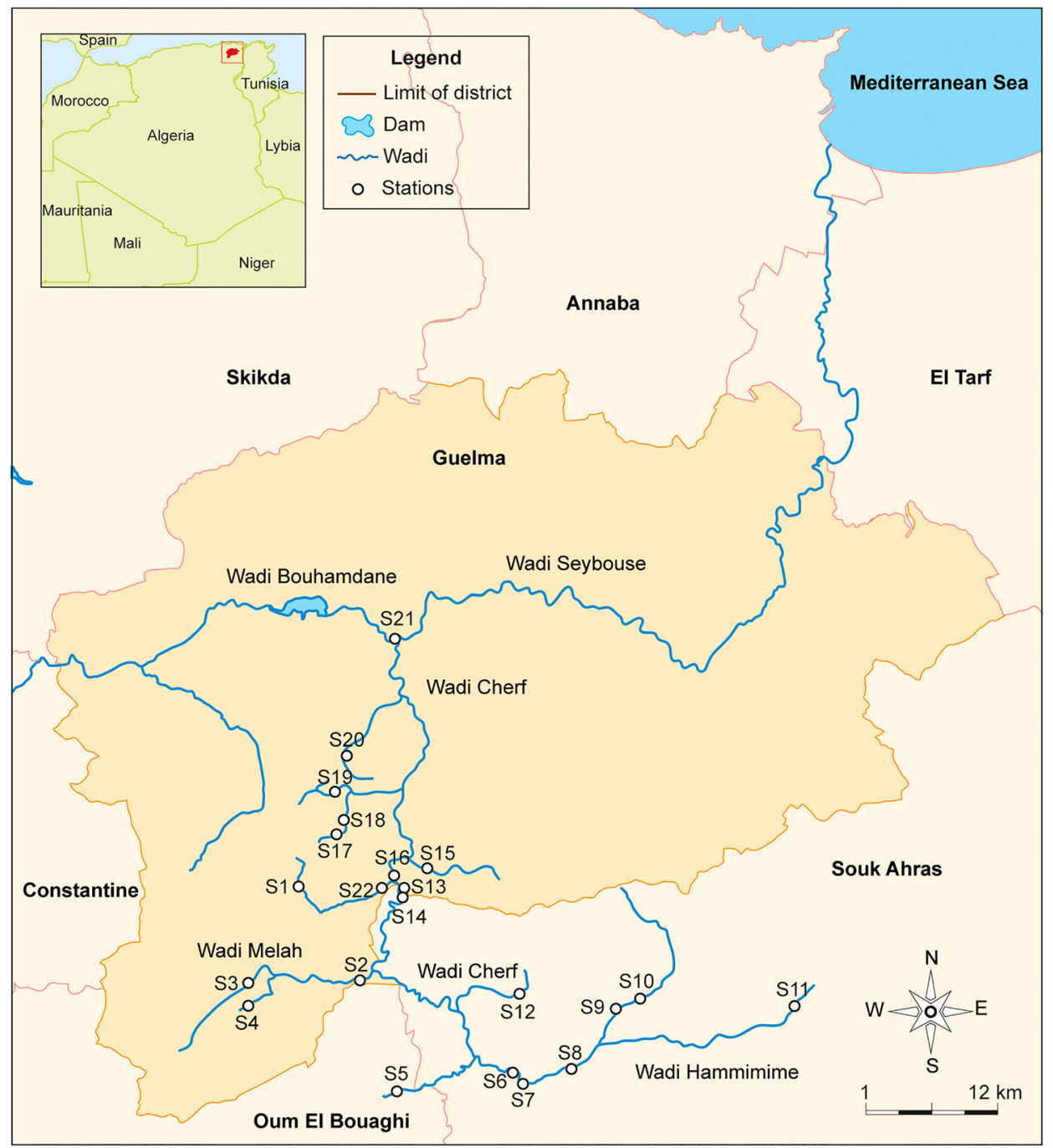

Figure 1. Localization of sampled stations in the catchment area of Wadi Charef.

either stage may provide valuable ecological information (Hawking \& New, 1999). However, larval sampling and identification is more challenging.

In addition, the main environmental variables were measured in situ using multi-probes at mid-water depth (water temperatures, conductivity, current speed, water depth, bed width, "hydroperiod", riparian vegetation cover (\%), and pollution) (Tables 1 and 2). Both substrate and "hydroperiod" were classified in a dichotomic way: hard/soft and permanent/intermittent (having a dry period), respectively. As a proxy to adjacent land use, pollution was measured on a scale from 1 (no obvious pollution) to 3 (severe pollution), based on the presence of algae, plastic debris, building material waste, and/or sewage. Intermediary stage 2 indicates the presence of waste products but to a much lesser extent than in stage 3. At each locality, macroinvertebrates and fish were also monthly collected using a dipnet. The status of recorded species originates from the Mediterranean and the North African IUCN Red Lists (Riservato et al., 2009; Samraoui 
Table 1. List of sampled localities with GPS coordinates. T, temporary habitat; P, permanent habitats.

\begin{tabular}{|c|c|c|c|c|c|}
\hline Code & Name & Hydroperiod & Altitude (m) & Latitude $(\mathrm{N})$ & Longitude (E) \\
\hline $\mathrm{S} 1$ & Beldjoudi & $\mathrm{T}$ & 822 & 36.2231 & 7.2144 \\
\hline $\mathrm{S} 2$ & Ben Mheni & $\mathrm{T}$ & 667 & 36.1506 & 7.2806 \\
\hline $\mathrm{S} 3$ & O. El Maleh & $\mathrm{T}$ & 748 & 36.1481 & 7.1439 \\
\hline $\mathrm{S} 4$ & Aïn Arko & $\mathrm{T}$ & 750 & 36.1264 & 7.1547 \\
\hline S5 & Oued Dahmane & $\mathrm{P}$ & 752 & 36.0531 & 7.3278 \\
\hline S6 & Sedrata dam & $\mathrm{P}$ & 746 & 36.0594 & 7.4553 \\
\hline S7 & Sedrata bridge II & $\mathrm{T}$ & 760 & 36.0522 & 7.4661 \\
\hline S8 & Sedrata bridge I & $\mathrm{P}$ & 765 & 36.0744 & 7.4942 \\
\hline S9 & Oued Krab & $\mathrm{P}$ & 784 & 36.1200 & 7.5461 \\
\hline S10 & Krab bridge & $\mathrm{T}$ & 800 & 36.1319 & 7.5711 \\
\hline S11 & Tiffech bridge & $\mathrm{T}$ & 860 & 36.1411 & 7.7544 \\
\hline S12 & Oued Nil & $\mathrm{T}$ & 864 & 36.1397 & 7.4458 \\
\hline S13 & Dbabcha & $\mathrm{P}$ & 610 & 36.2167 & 7.3181 \\
\hline S14 & Oued Aar & $\mathrm{T}$ & 617 & 36.2261 & 7.3197 \\
\hline S15 & Oued Cheniour & $\mathrm{P}$ & 602 & 36.2478 & 7.3433 \\
\hline S16 & Aïn Makhlouf bridge & $\mathrm{P}$ & 590 & 36.2397 & 7.3114 \\
\hline S17 & Aazlat Hlima & $\mathrm{T}$ & 770 & 36.2697 & 7.2836 \\
\hline S18 & Chaabet Bounab & $\mathrm{T}$ & 805 & 36.2847 & 7.2844 \\
\hline S19 & Oued Boufrais & $\mathrm{T}$ & 612 & 36.3158 & 7.2722 \\
\hline $\mathrm{S} 20$ & Selaoua & $\mathrm{T}$ & 589 & 36.3483 & 7.2672 \\
\hline $\mathrm{S} 21$ & Medjez Amar & $\mathrm{P}$ & 249 & 36.4431 & 7.3108 \\
\hline $\mathrm{S} 22$ & Aïn Makhlouf dam & $\mathrm{P}$ & 643 & 36.2261 & 7.2967 \\
\hline
\end{tabular}

et al., 2010). Sampling details and data analyses of macroinvertebrates and fish will be reported elsewhere.

\section{Statistical analysis}

Two-way ANOVA tests were used to compare mean differences of species richness and overall species abundance (response variables) in samples from localities with different pollution levels and "hydroperiod" (independent variables). Following the two-way ANOVA tests, we conducted Tukey multiple pairwise comparisons to distinguish between the means differences which were significantly different. Prior to the two-way ANOVA tests, both species richness and abundance were square root transformed and, because of the limited data set, pollution levels 3 and 4 were lumped together. To obtain a typology of odonate assemblages and rank environmental variables according to their importance in driving these assemblages, two principal component analyses (PCAs) were performed based on species abundance and environmental variables, respectively, using the package FactoMineR (Lê, Josse, \& Husson, 2008). PCA is an exploratory multivariate analysis and a dimension-reduction technique, most valuable in the presence of highly correlated variables.

In addition, co-inertia analysis (CIA), a two-table ordination method, has been used to ordinate samples by looking for a co-structure between environmental variables and odonates (Dolédec $\&$ Chessel, 1994). The significance of the correlation (RV) between the two sets of coordinates resulting from the CIA was tested by performing 10,000 CIAs of the abiotic variables and the odonate datasets after random permutations of their rows (Dolédec \& Chessel, 1994). The RV coefficient, which has a range of 0 to 1 , provides the overall measure of similarity of two data tables using a multivariate extension of the Pearson correlation coefficient. A high RV suggests a high degree of co-structure. All means are shown \pm standard deviation, unless stated otherwise and all statistical tests were performed using R software (R Development Core Team, 2018). 
Table 2. Physical and chemical data of sampled localities.

\begin{tabular}{|c|c|c|c|c|c|c|c|c|}
\hline Code & Locality & Temperature $\left({ }^{\circ} \mathrm{C}\right)$ & $\begin{array}{l}\text { Conductivity } \\
\left(\mu \mathrm{s} \mathrm{cm}^{-1}\right)\end{array}$ & $\begin{array}{l}\text { Water depth } \\
\quad(\mathrm{cm})\end{array}$ & Bedwidth (m) & $\begin{array}{l}\text { Current speed } \\
\qquad\left(\mathrm{m} \mathrm{s}^{-1}\right)\end{array}$ & Pollution & Veg. Cover $(\%)$ \\
\hline S1 & Beldjoudi & $14.9 \pm 5.2$ & $1016.2 \pm 430.4$ & $15.2 \pm 5.1$ & $2.1 \pm 1.0$ & $0.1 \pm 0.1$ & 3 & 40 \\
\hline $\mathrm{S} 2$ & Ben Mheni & $11.8 \pm 7.2$ & $884.8 \pm 620.0$ & $13.7 \pm 3.8$ & $7.0 \pm 4.6$ & $0.2 \pm 0.1$ & 1 & 10 \\
\hline S3 & O. El Maleh & $10.8 \pm 4.1$ & $1332.1 \pm 354.8$ & $14.7 \pm 4.9$ & $5.6 \pm 1.8$ & $0.2 \pm 0.1$ & 2 & 90 \\
\hline S4 & Ain Arko & $14.8 \pm 6.2$ & $1085.4 \pm 292.6$ & $12.1 \pm 4.3$ & $0.9 \pm 0.5$ & $0.2 \pm 0.1$ & 1 & 80 \\
\hline S5 & O. Dehmane & $18.1 \pm 5.8$ & $474.7 \pm 511.3$ & $18.8 \pm 6.2$ & $29.8 \pm 56.9$ & $0.1 \pm 0.1$ & 3 & 70 \\
\hline S6 & Sedrata dam & $17.3 \pm 6.5$ & $705.0 \pm 692.6$ & $18.2 \pm 7.3$ & $107.0 \pm 45.2$ & $0.1 \pm 0.1$ & 2 & 70 \\
\hline S7 & Sedrata bridge 1 & $16.9 \pm 5.9$ & $929.6 \pm 770.6$ & $43.1 \pm 28.1$ & $6.1 \pm 1.3$ & $0.1 \pm 0.1$ & 2 & 20 \\
\hline S8 & Sedrata bridge 2 & $13.9 \pm 5.7$ & $486.3 \pm 628.4$ & $16.9 \pm 6.5$ & $6.8 \pm 3.6$ & $0.2 \pm 0.1$ & 1 & 80 \\
\hline S9 & O. Krab & $18.4 \pm 6.1$ & $1125.1 \pm 505.4$ & $32.1 \pm 16.6$ & $10.8 \pm 4.1$ & $0.2 \pm 0.1$ & 2 & 20 \\
\hline S10 & Krab bridge & $17.9 \pm 6.6$ & $967.6 \pm 423.7$ & $19.9 \pm 11.8$ & $2.7 \pm 1.7$ & $0.1 \pm 0.1$ & 3 & 70 \\
\hline S11 & Tiffech bridge & $15.2 \pm 6.1$ & $612.2 \pm 201.3$ & $25.7 \pm 11.9$ & $5.0 \pm 1.5$ & $0.2 \pm 0.3$ & 1 & 70 \\
\hline $\mathrm{S} 12$ & O. Nil & $16.6 \pm 5.0$ & $1094.2 \pm 642.7$ & $17.6 \pm 6.4$ & $2.6 \pm 1.0$ & $0.3 \pm 0.2$ & 1 & 10 \\
\hline $\mathrm{S} 13$ & Dbebcha & $19.1 \pm 7.0$ & $688.2 \pm 684.7$ & $20.5 \pm 7.0$ & $14.7 \pm 7.7$ & $0.3 \pm 0.1$ & 2 & 10 \\
\hline S14 & O. El Aar & $18.6 \pm 8.1$ & $626.3 \pm 266.2$ & $14.2 \pm 5.0$ & $2.9 \pm 1.6$ & $0.4 \pm 0.3$ & 1 & 10 \\
\hline S15 & O. Cheniour & $18.1 \pm 4.7$ & $512.7 \pm 152.7$ & $18.2 \pm 6.7$ & $2.0 \pm 1.2$ & $0.3 \pm 0.2$ & 1 & 20 \\
\hline S16 & Ain Makhlouf bridge & $18.8 \pm 6.6$ & $756.5 \pm 618.3$ & $30.0 \pm 16.6$ & $9.3 \pm 5.6$ & $0.3 \pm 0.2$ & 3 & 20 \\
\hline S17 & Azlet Hlima & $11.4 \pm 4.4$ & $580.7 \pm 137.1$ & $15.0 \pm 5.1$ & $1.1 \pm 0.4$ & $0.3 \pm 0.3$ & 1 & 20 \\
\hline S18 & Chabet Bounab & $15.1 \pm 7.2$ & $474.5 \pm 289.6$ & $12.2 \pm 8.6$ & $7.6 \pm 4.5$ & $0.3 \pm 0.2$ & 1 & 70 \\
\hline S19 & O. Boufrais & $13.9 \pm 4.6$ & $1000.9 \pm 332.5$ & $13.8 \pm 4.8$ & $3.0 \pm 1.4$ & $0.2 \pm 0.1$ & 1 & 60 \\
\hline S20 & Selaoua & $17.3 \pm 4.8$ & $664.2 \pm 143.5$ & $20.0 \pm 6.5$ & $3.5 \pm 1.3$ & $0.1 \pm 0.1$ & 1 & 10 \\
\hline S21 & Medjez Amar & $20.3 \pm 6.9$ & $925.5 \pm 645.3$ & $27.6 \pm 12.4$ & $19.1 \pm 12.1$ & $0.4 \pm 0.3$ & 3 & 10 \\
\hline S22 & Ain Makhlouf dam & $16.6 \pm 5.1$ & $786.0 \pm 249.2$ & $17.5 \pm 5.9$ & $1.9 \pm 0.7$ & $0.2 \pm 0.2$ & 2 & 70 \\
\hline
\end{tabular}


Table 3. Checklist of recorded odonates at Wadi Cherf with list of localities.

\begin{tabular}{|c|c|c|c|}
\hline Num & Family & Species & Localities \\
\hline 1 & Calopterygidae & Calopteryx exul Selys, 1853 & $\mathrm{~S} 10, \mathrm{~S} 13, \mathrm{~S} 15$ \\
\hline 2 & & $\begin{array}{l}\text { Calopteryx haemorrhoidalis (Vander } \\
\quad \text { Linden, 1825) }\end{array}$ & $\begin{array}{l}\mathrm{S} 1, \mathrm{~S} 9, \mathrm{~S} 10, \mathrm{~S} 13, \mathrm{~S} 15 \\
\mathrm{~S} 21, \mathrm{~S} 22\end{array}$ \\
\hline 3 & Lestidae & Chalcolestes viridis (Vander Linden, 1825) & $\mathrm{S} 13, \mathrm{~S} 22$ \\
\hline 4 & Coenagrionidae & Ischnura graellsii (Rambur, 1842) & $\begin{array}{l}\mathrm{S} 1, \mathrm{~S} 3-10, \mathrm{~S} 13, \mathrm{~S} 14, \mathrm{~S} 16 \\
\mathrm{~S} 17, \mathrm{~S} 19, \mathrm{~S} 21, \mathrm{~S} 22\end{array}$ \\
\hline 5 & & Ischnura pumilio (Charpentier, 1825) & $\mathrm{S} 3, \mathrm{~S} 4, \mathrm{~S} 8, \mathrm{~S} 22$ \\
\hline 6 & & $\begin{array}{l}\text { Coenagrion caerulescens (Fonscolombe, } \\
1838 \text { ) }\end{array}$ & $\begin{array}{l}\text { S4-6, S8-11, S16, S19, } \\
\quad \text { S21 }\end{array}$ \\
\hline 7 & & Coenagrion mercuriale (Charpentier, 1840) & $\mathrm{S} 1, \mathrm{~S} 4, \mathrm{~S} 5, \mathrm{~S} 7-10, \mathrm{~S} 22$ \\
\hline 8 & & Erythromma lindenii (Selys, 1840) & $\begin{array}{l}\text { S1, S4, S8, S9, S16, S21, } \\
\text { S22 }\end{array}$ \\
\hline 9 & & Ceriagrion tenellum(de Villers, 1789) & $\mathrm{S} 1, \mathrm{~S} 10$ \\
\hline 10 & Platycnemididae & $\begin{array}{l}\text { Platycnemis subdilatata Selys in Lucas, } \\
1849\end{array}$ & $\begin{array}{l}\text { S1, S4-12, S14, S16-18, } \\
\text { S22, S23 }\end{array}$ \\
\hline 11 & Aeshnidae & Anax imperator Leach in Brewster, 1815 & $\mathrm{~S} 7, \mathrm{~S} 11, \mathrm{~S} 20$ \\
\hline 12 & & Anax parthenope (Selys, 1839) & S6 \\
\hline 13 & Gomphidae & Gomphus lucasii Selys in Lucas, 1849 & $\mathrm{~S} 13, \mathrm{~S} 16, \mathrm{~S} 22$ \\
\hline 14 & & Onychogomphus costae Selys, 1885 & $\mathrm{~S} 14, \mathrm{~S} 16$ \\
\hline 15 & & $\begin{array}{l}\text { Onychogomphus forcipatus unguiculatus } \\
\text { (Vander Linden, 1820) }\end{array}$ & S14 \\
\hline 16 & Libellulidae & $\begin{array}{l}\text { Orthetrum coerulescens anceps (Schneider, } \\
1845 \text { ) }\end{array}$ & $\mathrm{S} 10, \mathrm{~S} 11$ \\
\hline 17 & & Orthetrum nitidinerve (Selys, 1841) & S5, S9, S10, S17 \\
\hline 18 & & Crocothemis erythraea (Brullé, 1832) & $\mathrm{S} 8, \mathrm{~S} 22$ \\
\hline 19 & & Sympetrum fonscolombii (Selys, 1840) & $\mathrm{S} 1, \mathrm{~S} 10, \mathrm{~S} 11, \mathrm{~S} 16, \mathrm{~S} 22$ \\
\hline 20 & & Sympetrum meridionale (Selys, 1841) & $\mathrm{S} 10$ \\
\hline 21 & & Sympetrum striolatum (Charpentier, 1840) & $\mathrm{S} 1, \mathrm{~S} 4, \mathrm{~S} 11, \mathrm{~S} 21$ \\
\hline
\end{tabular}

\section{Results}

We collected 537 adults with a biased sex-ratio of 326 males to 211 females. A total of 21 species belonging to 13 genera and seven families were identified (Table 3). Two zygopterans, Ischnura graellsii and the Maghrebian endemic Platycnemis subdilatata, were the most abundant and most widespread, being found at 16 of the 22 sampled stations (Figure 2). Two more species, C. exul (EN) and Gomphus lucasii (EN), are considered threatened on both the Mediterranean and the North African IUCN Red Lists. In addition, Coenagrion mercuriale (EN) is considered threatened on the North African Red List while being assessed as NT on the Mediterranean Red List. Another species, Onychogomphus costae, figures as NT on both IUCN Red Lists.

The flight period stretched between April and November with adults' abundance and species richness peaking in June. Species richness varied markedly along the watercourse stations from 0 (S2, S12 and S18) to 11 (S10) (Figure 3). Once our null hypothesis of an absence of interaction between pollution and hydroperiod was corroborated for species richness (two-way ANOVA: $\mathrm{F}_{2,16}=3.57, p=0.052$ ) and abundance (two-way ANOVA: $\mathrm{F}_{2,16}=2.52, p=0.112$ ), we fitted an additive model which indicated that both pollution (two-way ANOVA: $\mathrm{F}_{2,18}=3.94$, $p=0.038$ ) and hydroperiod (two-way ANOVA: $\mathrm{F}_{1,18}=5.42, p=0.032$ ) had a marginal influence on species richness. Tukey multiple pairwise-comparisons indicated a marginal difference in mean species richness between unpolluted sites (1) and polluted sites (3) ( $p=0.055)$ (Figure 4a). In addition, Odonates' abundance was also significantly influenced by pollution (two-way ANOVA: $\left.\mathrm{F}_{2,18}=7.44, p=0.004\right)$ while hydroperiod had no effect $\left(\mathrm{F}_{1,18}=3.40, p=\right.$ 0.082). Tukey multiple pairwise-comparisons indicated a highly significant difference between unpolluted sites (1) and polluted sites (3) ( $p=0.007$ ) (Figure 4b). 


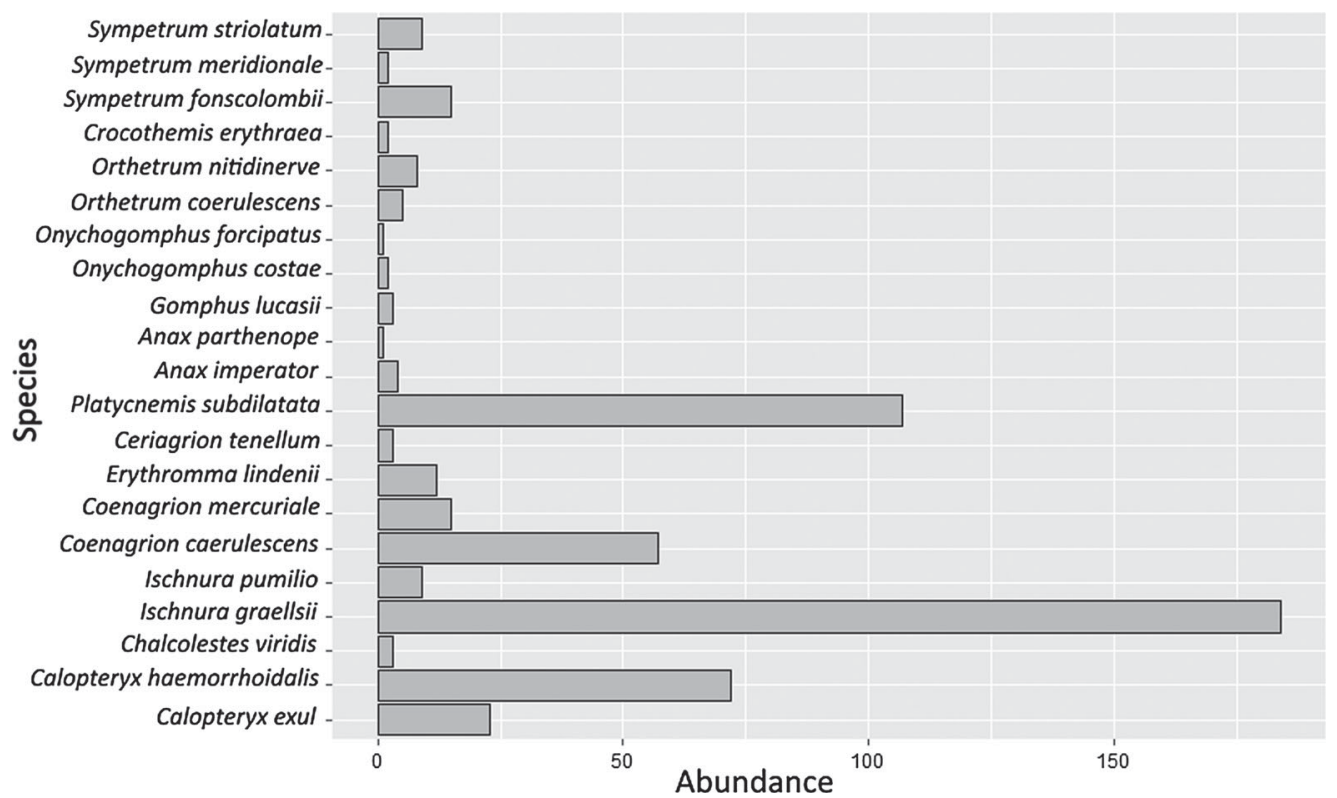

Figure 2. Barplot of species' abundance at Wadi Cherf.

PCA of the measured descriptors indicated a substantial variation of the physico-chemical properties among the sampling sites (Figure 5). The first four components represented $77.3 \%$ of the total variance. The first component (30.3\% of the inertia) was associated with the altitudinal gradient and the vegetation cover that opposed lower temperature, upstream habitats with a dense vegetation (S1, S3, S4) to warmer, sparsely vegetated downstream sites (S13, S15, S16, S21). The second component (23.6\% of the total inertia) separated fast-flowing, intermittent, narrow streams with relatively clean waters and hard substrates (S2, S17) to slow-flowing, permanent wider stretches of the watercourse with polluted waters and clay and sand-dominated substrates (S5, S6). The third component (14.4\% of the total inertia) isolated sites with high conductivity and water depth (S7) from sites with comparatively low conductivity and water level (S6, S8). Similarly, the fourth and most minor component (8.8\% of the inertia) opposed downstream sites with relatively high conductivity (S3, S21) to upstream sites with low conductivity (S7, S11). The results indicated some degree of collinearity between a number of environmental factors (e.g. vegetation cover and altitude).

The first three components of the PCA based on the odonate matrix totaled $48.8 \%$ of the total variance (Figure 6). The first component (18.5\%) separated species-rich sites such as S9 and S10 inhabited by Calopteryx haemorrhoidalis, Ceriagrion tenellum, and Orthetrum chrysostigma from species-poor sites (S2, S12, S18). The second component (17.0\% of the inertia) set apart a site (S22) adjacent to a reservoir and characterized by lentic species (Sympetrum fonscolombii, Crocothemis erythraea) found along lotic species (Coenagrion mercuriale and Erythromma lindenii). The third component (13.3\% of the inertia) segregated nutrient-rich sites dominated by helophytes inhabited by Ischnura pumilio and Coenagrion caerulescens from less-polluted sites with riparian vegetation dominated by $C$. exul, G. lucasii and Chalcolestes viridis.

CIA coupled the fauna and descriptors matrices and organized the odonate assemblages of Wadi Cherf along the first axis (70.4\% of the total inertia) that segregated polluted sites with high water temperatures and soft substrates occupied by I. graellsii and P. subdilatata from cleaner sites with fast-flowing current and hard substrate (Figure 7a). The second axis (17.6\% of the total inertia) expressed an altitudinal gradient which opposed high altitude intermittent 

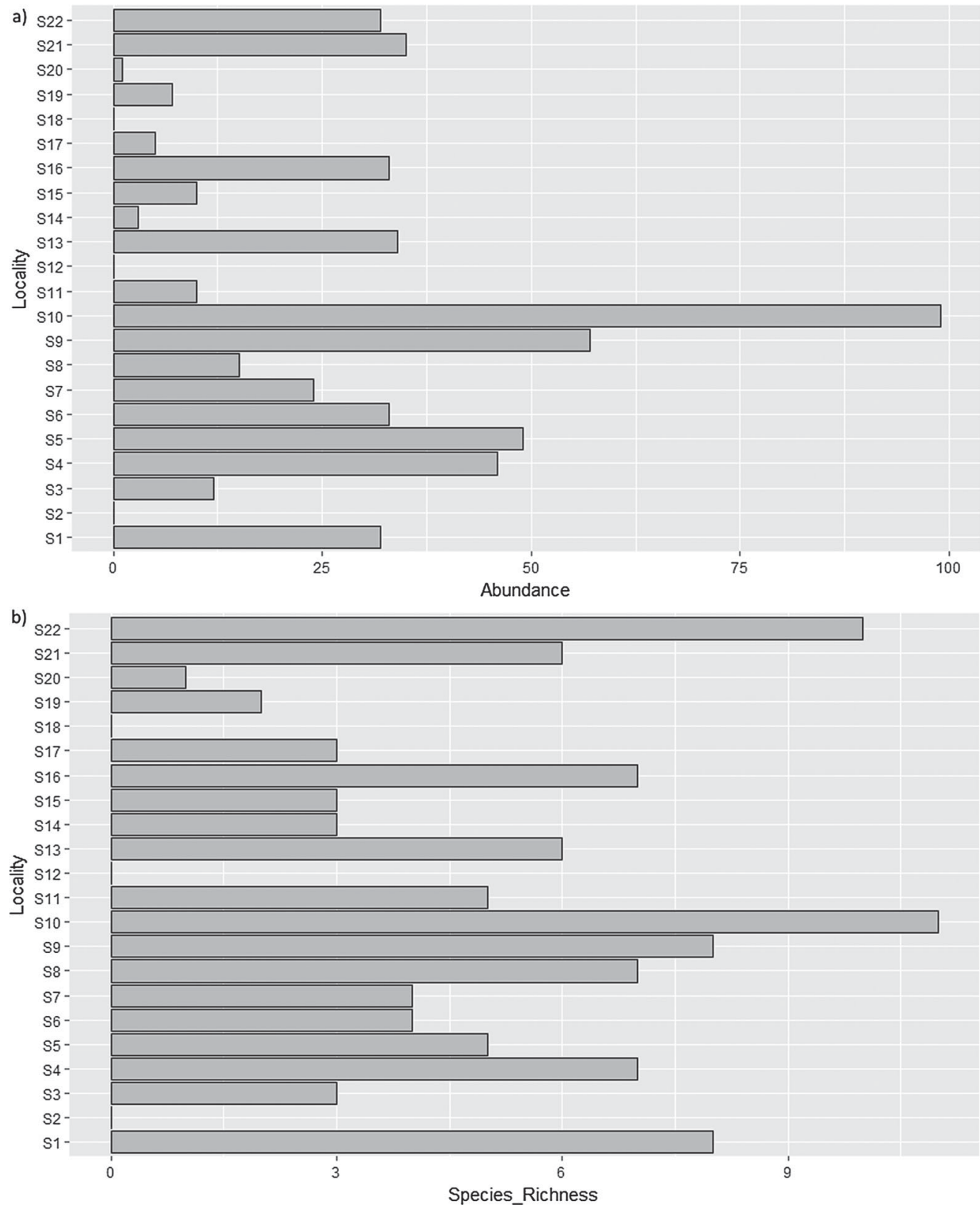

Figure 3. (a) Total abundance and (b) species richness of odonates at sampled localities of Wadi Cherf.

sites with dense vegetation, dominated by $C$. haemorrhoidalis and C. caerulescens, to downstream fast-flowing permanent sites with high water depth dominated by $P$. subdilatata. The RV-coefficient, an index of the strength of the relationship between the two tables, was 0.26 . A potential co-structure was tested using a permutation test which, however, indicated an only marginally significant relationship ( $p=0.12$ ) (Figure $7 \mathrm{~b}$ ). 


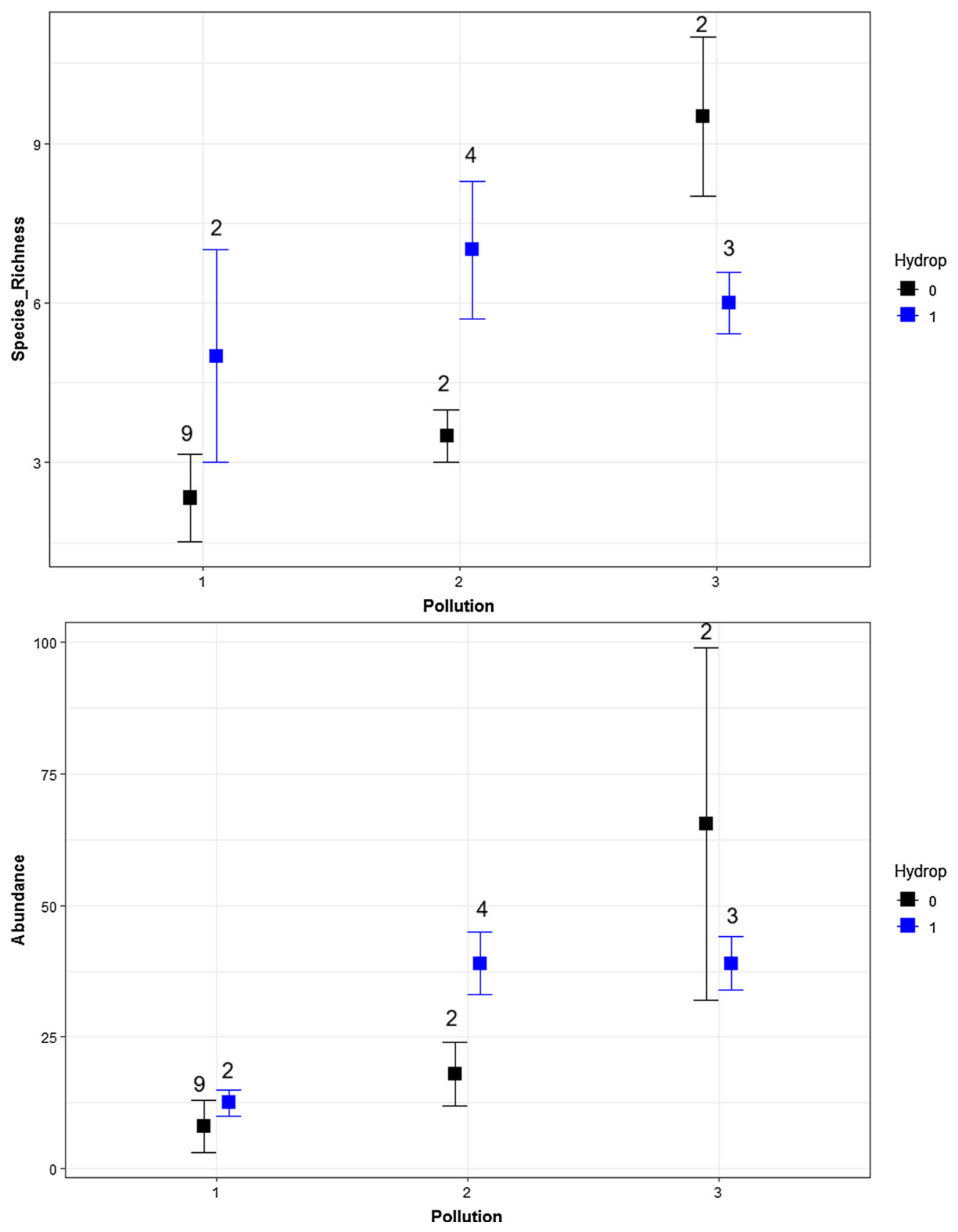

Figure 4. Interaction plot of pollution and hydroperiod for a two-way ANOVA of (a) species richness and (b) abundance. Square points represent means, and error bars indicate standard errors of the mean.

\section{Discussion}

Noteworthy is the finding of two new localities for the Endangered Maghrebian endemic C. exul (Figure 8a) which is recorded to be locally abundant in one of these two sites. Over the last three decades and despite extensive efforts across Algeria, C. exul has never been found outside the 
a)

Variables factor map (PSA)
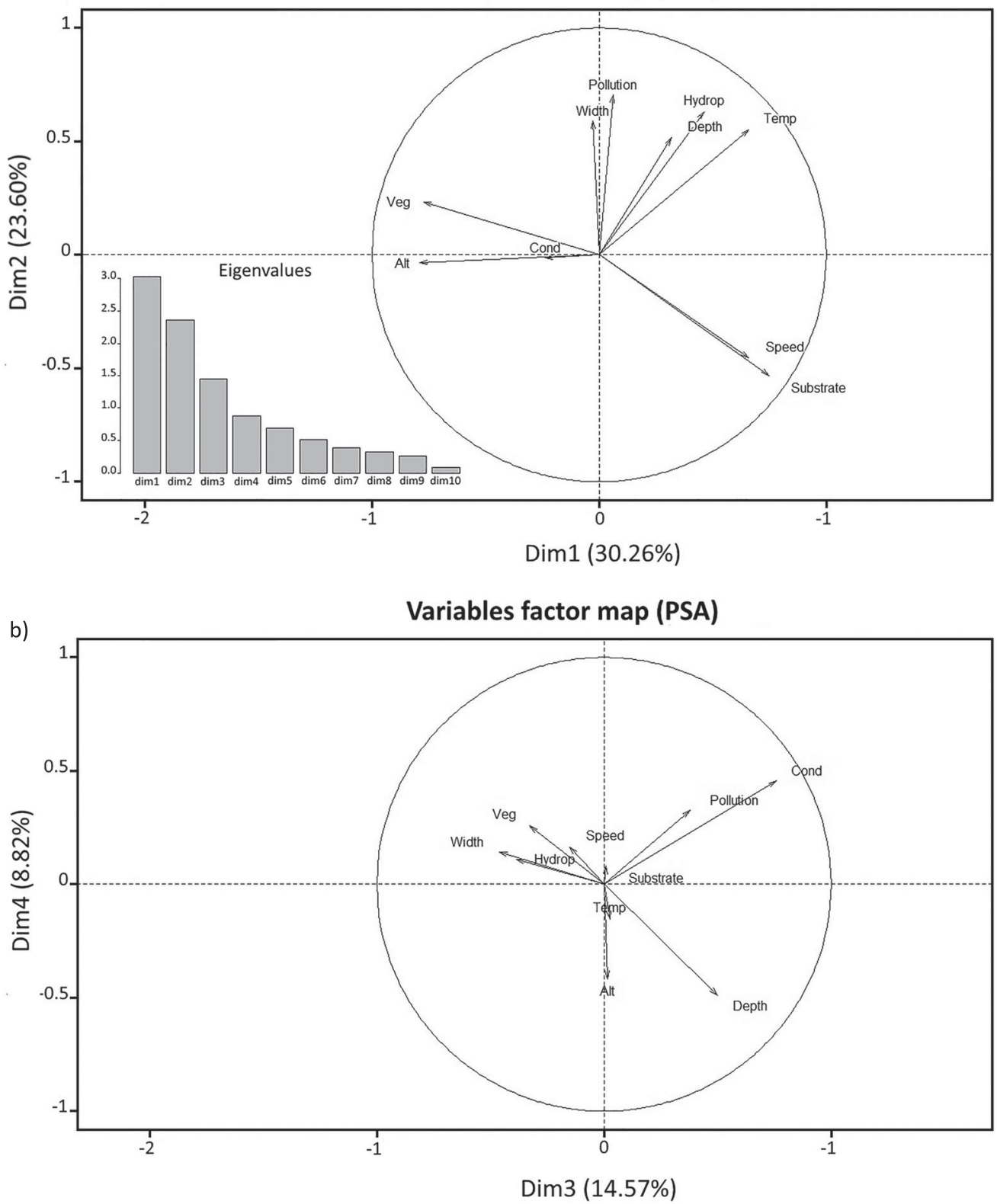

Figure 5. Descriptors factor map of principal component analysis with scree plot (inset). (a) First two components and (b) components three and four.

River Seybouse and its affluents which can be considered as a hotspot for Mediterranean freshwater biodiversity (Riservato et al., 2009). Wadi Cherf is also a sanctuary for another Vulnerable Maghrebian endemic, G. lucasii (Figure 8b), and the Endangered C. mercuriale.

This study also indicated that while the flight period stretched between April and October for the majority of recorded species, some species, e.g. C. viridis, were observed flying up to November, as shown by previous studies (Agüero-Pelegrín, Ferreras-Romero \& Corbet, 1999; Ferreras-Romero \& Márquez-Rodríguez, 2014; Samraoui, 2009). Temporal abundance and 
a)

Variables factor map (PSA)

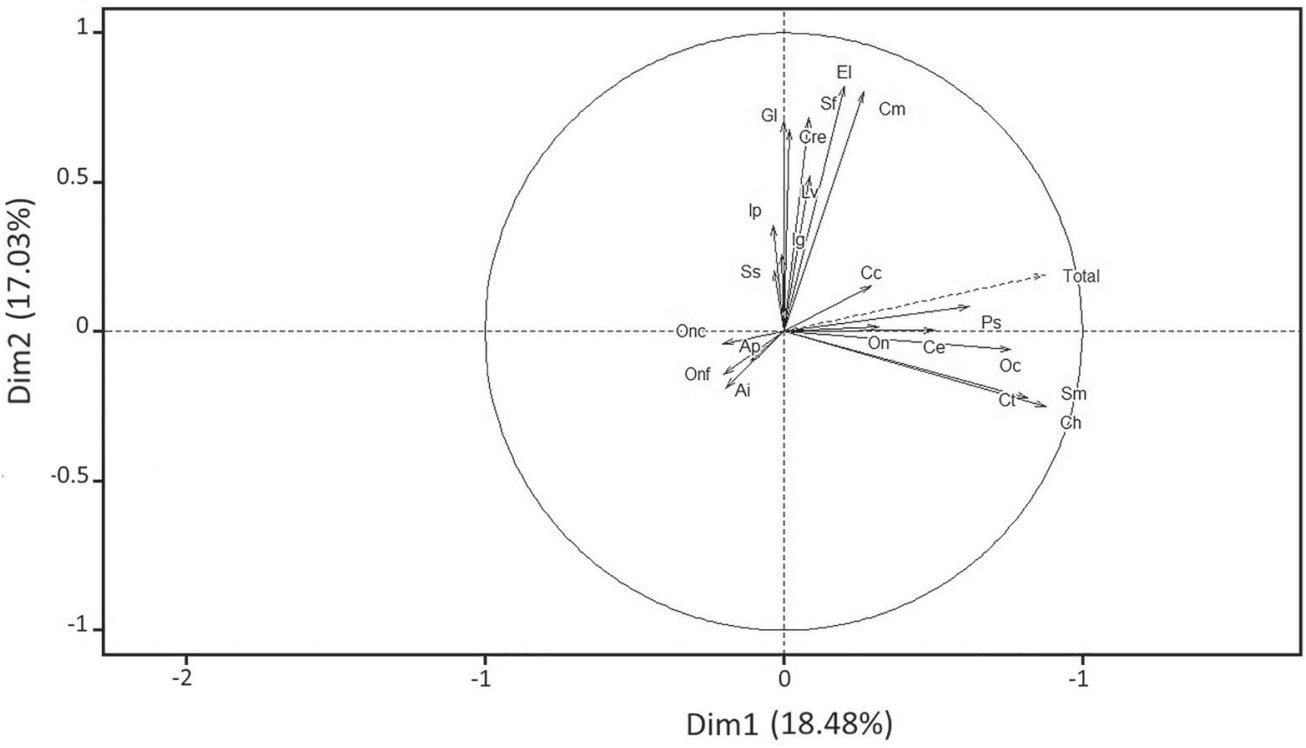

b) $\quad$ Variables factor map (PSA)

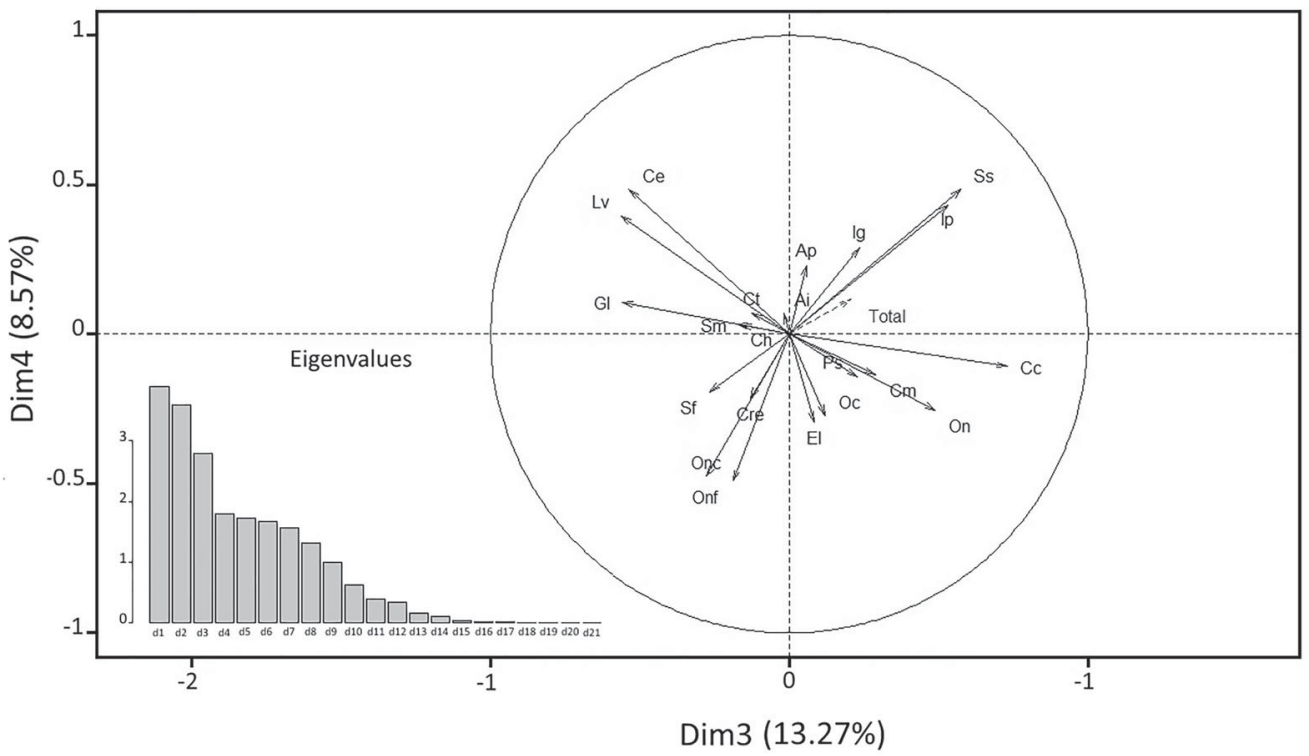

Figure 6. Species factor map of principal component analysis with scree plot (inset). (a) First two components and (b) components three and four.

species richness were highest in June, a result congruent with a previous study in northeastern Algeria (Samraoui \& Corbet, 2000b).

Four localities, S1, S9, S10, and S22, had the highest species richness and were the most abundant. A strong association was found between the odonate assemblages and the pollution status of the habitat. Interestingly, all four richest localities were subjected to moderate water abstraction and agricultural runoff. 


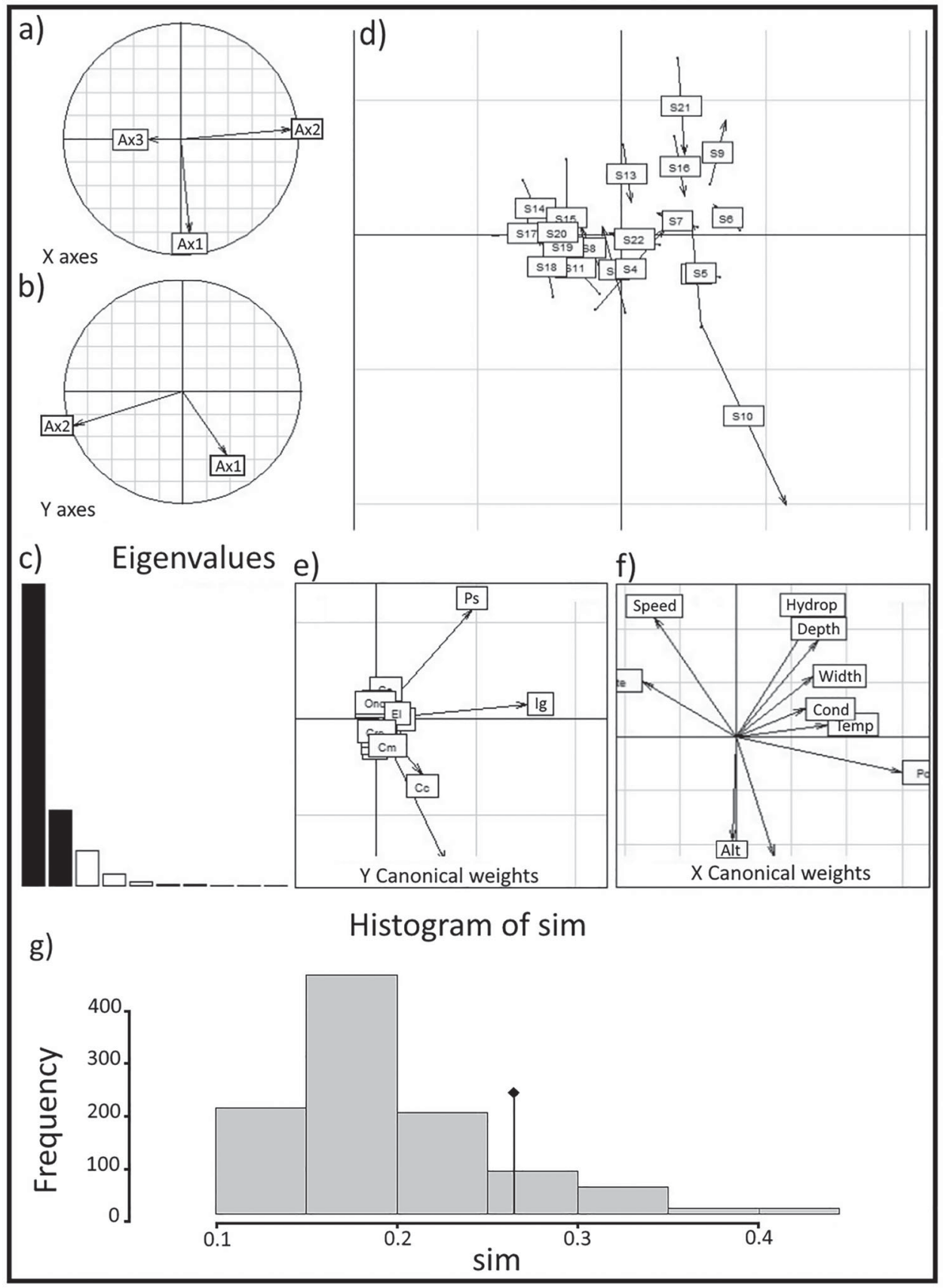

Figure 7. Results of the co-inertia analysis (CIA) using recorded Odonata abundance and measures of environmental descriptors at Wadi Cherf. (a) Components of the standardized principal component analysis of the environmental dataset projected onto the co-inertia axes; and (b) components of the centered principal component analysis of the odonatological data set projected onto the co-inertia axes. (c) Distribution of eigenvalues of CIA. (d) F1 $\times$ F2 factorial plane of CIA with arrows linking localities according to physico-chemical descriptors (base of arrows) and Odonata (end of arrows). (e) Distribution of species on the F1 $\times$ F2 factorial plane of CIA. (f) Distribution of environmental descriptors on the F1 $\times$ F2 factorial plane of CIA. (g) Results of the permutation test to measure the strength of the relationship between the two tables (species/descriptors). 


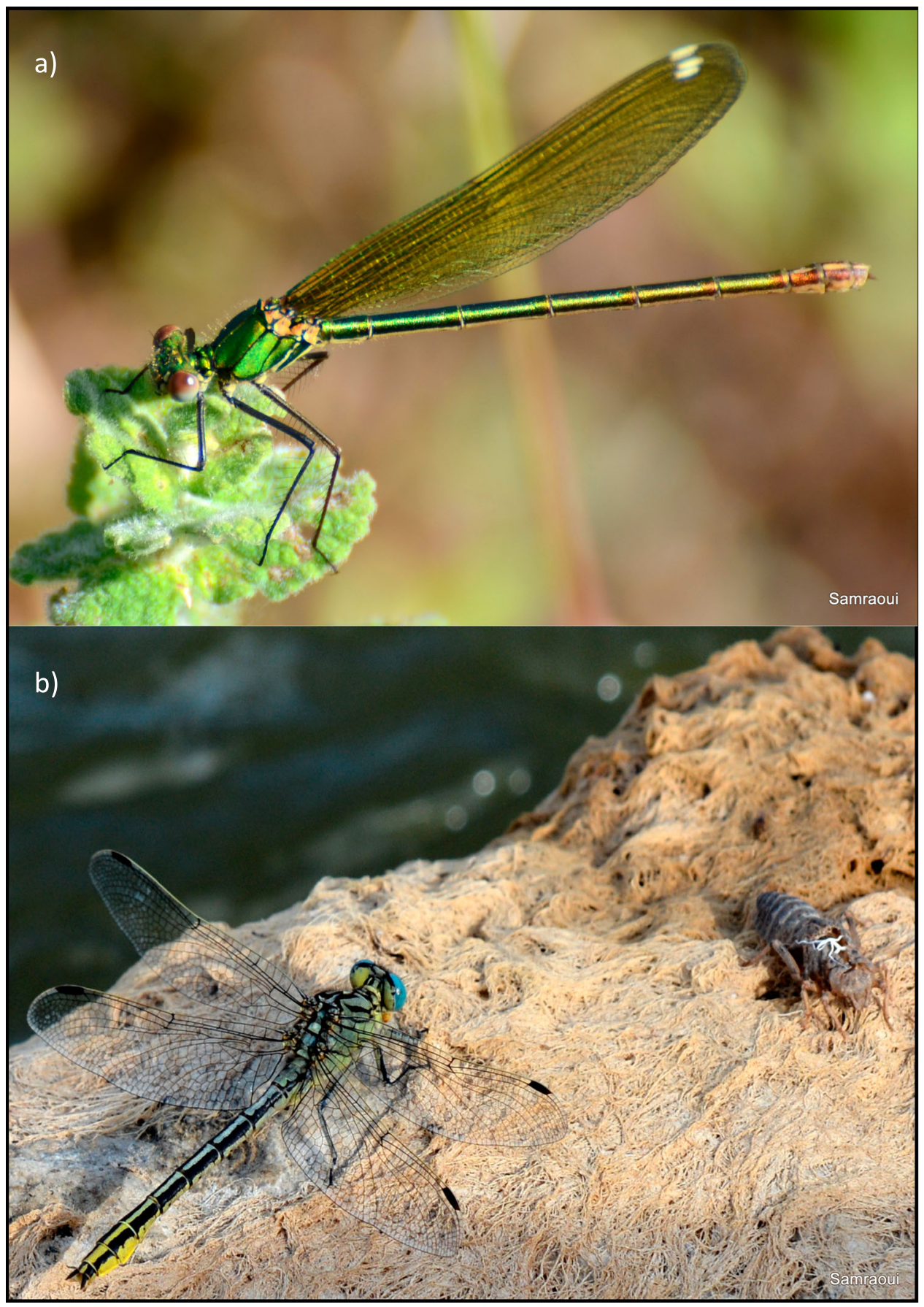

Figure 8. Close-up views of the threatened Maghrebian endemics (a) Calopteryx exul and (b) Gomphus lucasii.

A quadratic effect of disturbance has been shown in other Algerian wadis (Bouchelouche, Kherbouche-Abrous, Mebarki, Arab \& Samraoui, 2015; Hafiane et al., 2016), but the underlying processes are not clear. Whether pollution may favor species richness at intermediate levels (Connell, 1978; Wilkinson, 1999) is still a contentious issue (Fox, 2013) and nonsignificant, 
unimodal and monotonic relationships between diversity and one of many characteristics of ecological communities (productivity, disturbance, spatial and temporal heterogeneities, predation, etc.) may occur with similar frequencies (Gillman \& Wright, 2006).

Equally important, our results indicated congruence between both $P$. subdilatata and I. graellsii and polluted sites. Some odonates, like Ischnura spp., are well known for their capacity to withstand pollution (Campos et al., 2014; Ferreras-Romero, Márquez-Rodríguez, \& RuizGarcía, 2009; Solimini, Tarallo \& Carchini, 1997; Yalles-Satha \& Samraoui, 2017). This finding provides support to the reliability of our pollution index at detecting water quality deterioration.

At the same time, our results indicated an association between intermittent/permanent habitat and odonate community structure. Permanent sites which were unpolluted or had low levels of pollution had a higher abundance of adults and a higher species richness than equivalent intermittent sites, suggesting that drought may affect local Odonata assemblages. Drought is recognized as an important stressor of Mediterranean hydrosystems which are exposed to a seasonal sequence of extreme flooding and drying, driven by a wide range of natural and anthropogenic disturbances (Bond, Lake \& Arthington, 2008; Gasith \& Resh, 1999; Hershkovitz \& Gasith, 2013). Thus, it is expected that Mediterranean odonates' life history traits would be shaped by habitat and disturbances (Ferreras-Romero \& García-Rojas, 1995; Samraoui, Bouzid, Boulahbal \& Corbet, 1998; Schridde \& Suhling, 1994; Statzner, Doledec \& Hugueny, 2004) and their assemblages might reflect these selective pressures.

Because of increased demands of fresh water for human welfare, water abstraction for agriculture is widespread in North Africa and the presence of large dams and small impoundments alters flow regime, decreases ecosystem connectivity and exacerbates the impact of pollution (Karaouzas, Theodoropoulos, Vardakas, Kalogianni \& Skoulikidis, 2018) with severe impact on macroinvertebrate communities (Bredenhand \& Samways, 2009).

The PCA results suggested that pollution was collinear to both bed width and water conductivity. High values of electrical conductivity often indicate the presence of pollutants affecting water quality (Ding et al., 2015; Loock, Beukes \& van Zyl, 2015). The results also showed that both environmental factors and odonates exhibited a significant altitudinal gradient, a result shown previously in the Middle and Lower Seybouse (Yalles-Satha \& Samraoui 2017). As found in other studies (Allan, 1975; Culp \& Davies, 2011; Hawking \& New, 1999; Suhling, 2001; Ward \& Voelz, 1998), this longitudinal zonation was associated with factors such as water flow, temperature, conductivity, substrate, pollution, bed width, vegetation cover, and biotic interactions. As a result, pollution-tolerant species like I. graellsii or P. subdilatata could be found in degraded habitats, whereas threatened and endemic species like $C$. exul and G. lucasii were confined to relatively well-preserved habitats with relatively clean water and well-preserved riverine vegetation. The CIA confirmed the presence of a longitudinal gradient but the co-structure between the fauna and the environmental descriptors could not be statistically demonstrated, possibly because of the limited number of sampling stations. Alternatively, other unmeasured factors could influence the distribution of odonates along Wadi Cherf.

Equally important are interspecific interactions to understand species co-occurrence (Schoener, 1982; Suhling, 1999) which may inform us on mechanisms by which species are distributed and whether they may coexist (Chesson, 2000; McPeek \& Brown, 2000; Suhling, 1996). For example, the resilience of stressed macroinvertebrate communities is frequently tested by the colonization of degraded habitats by opportunistic, thermophilic, and highly dispersive species (Hafiane et al., 2016). The steady invasion of stressed North African wadis by thermophilic species (Paragomphus genei, Brachythemis impartita, Diplacodes lefebvrii, Trithemis arteriosa and T. kirbyi) and the concomitant extinction of threatened species has been well document in the region (Morghad et al., 2019; Yalles-Satha \& Samraoui, 2017). 


\section{Conservation}

If considerable efforts over the last decades have been directed towards the protection of freshwater habitats, these efforts have been mainly focused on lentic habitats like freshwater lakes, salt lakes and ponds, and their vertebrate (mainly birds) communities (Samraoui \& Samraoui, 2008). An indication of the neglected and sorry state of North African freshwater habitats is the proportion of threatened species in the region, which is higher, at $24.4 \%$, than the $10 \%$ assessed worldwide (Clausnitzer et al., 2009; Samraoui et al., 2010).

Our results indicate that the upstream region of Wadi Cherf is still able to host threatened species confined to upstream habitats, relatively well preserved. Therefore, conservation efforts need to prioritize these habitats for protection. Unfortunately, neither wadis nor invertebrates figure prominently in Algeria's conservation strategy and unless urgent steps are taken to mitigate the current rate of habitat degradation and biodiversity loss of rivers and streams in North Africa, the ongoing anthropogenic pressures will disrupt the functioning of lotic ecosystems with ineluctable adverse consequences for human livelihoods in an already water-stressed region (Droogers et al., 2012; Islam \& Susskind, 2015).

\section{Acknowledgements}

We are most grateful to an anonymous reviewer for valuable comments on our manuscript. This study was supported by the Algerian Ministère de l'Enseignement Supérieur et de la Recherche Scientifique (M.E.S.R.S.).

\section{ORCID}

Farrah Samraoui (D) http://orcid.org/0000-0003-2407-3004

Boudjéma Samraoui (D) http://orcid.org/0000-0002-0608-9021

\section{References}

Agüero-Pelegrín, M., Ferreras-Romero, M., \& Corbet, P. S. (1999). The life cycle of Lestes viridis (Odonata: Lestidae) in two seasonal streams of the Sierra Morena Mountains (southern Spain). Aquatic Insects, 21, $187-196$. doi:10.1076/aqin.21.3.187.4522

Allan, J. D. (1975). The distributional ecology and diversity of benthic insects in Cement Creek, Colorado. Ecology, 56, 1040-1053. doi:10.2307/1936145

Bond, N. R., Lake, P. S., \& Arthington, A. H. (2008). The impacts of drought on freshwater ecosystems: an Australian perspective. Hydrobiologia, 600, 3-16. doi:10.1007/s10750-008-9326-Z

Bouchelouche, D., Kherbouche-Abrous, O., Mebarki, M., Arab, A., \& Samraoui, B. (2015). Odonata of Wadi Isser (Kabylia, Algeria): Status and environmental determinants of their distribution. Revue d'Ecologie (Terre \& Vie), 70 , $248-260$.

Boudot, J.-P., Kalkman, V. J., Azpilicueta Amorín, M., Bogdanović, T., Cordero Rivera, A., Degabriele, G., ... Schneider, W. (2009). Atlas of the Odonata of the Mediterranean and North Africa. Libellula Supplement, 9 , $1-256$.

Bredenhand, E., \& Samways, M. J. (2009). Impact of a dam on benthic macroinvertebrates in a small river in a biodiversity hotspot: Cape Floristic Region, South Africa. Journal of Insect Conservation, 13, $297-307$. doi:10.1007/s10841-008-9173-2

Bried, J. T., \& Samways, M. J. (2015). A review of odonatology in freshwater applied ecology and conservation science. Freshwater Science, 34, 1023-1031. doi:10.1086/682174

Campos, F., Velasco, T., Sanz, G., Casanueva, P., Albuquerque, M. T. D., \& Antunes, I. M. H. R. (2014). Ischnura graellsii (Insecta: Odonata). A water pollution biovulnerability indicator - Probability mapping using spatial uncertainty. River Research and Applications, 32, 483-489. doi:10.1002/rra.2839

Chesson, P. (2000). Mechanism of maintenance of species diversity. Annual Review of Ecology and Systematics, 31, 343-366. doi:10.1146/annurev.ecolsys.31.1.343

Clausnitzer, V., Kalkman, V. J., Ram, M., Collen, B., Baillie, J. E. M., Bedjanic, M., ... Wilson, K. (2009). Odonata enter the biodiversity crisis debate: the first global assessment of an insect group. Biological Conservation, 142, 1864-1869. doi:10.1016/j.biocon.2009.03.028

Connell, J. H. (1978). Diversity in tropical rain forests and coral reefs. Science, 199, 1302-1310. doi:10.1126/science.199. 4335.1302 
Corbet, P. S. (1999). Dragonflies: Behavior and ecology of Odonata. Ithaca: Cornell University Press. doi:10.1076/ aqin.23.1.83.4929

Culp, J. M., \& Davies, R. (2011). Analysis of longitudinal zonation and the river continuum concept in the Oldman-South Saskatchewan River system. Canadian Journal of Fisheries and Aquatic Sciences, 39, $1258-1266$. doi:10.1139/f82-167

Ding, J., Jiang, Y., Fu, L., Liu, Q., Peng, Q., \& Kang, M. (2015). Impacts of land use on surface water quality in a subtropical river basin: a case study of the Dongjiang River Basin, southeastern China. Water SA, 7, 4427-4445. doi: $10.3390 /$ w7084427

Dolédec, S. \& Chessel, D. (1994). Co-inertia analysis: an alternative method for studying species-environment relationships. Freshwater Biology, 31, 277-294. doi:10.1111/j.1365-2427.1994.tb01741.x

Droogers, P., Immerzeel, W. W., Terink, W., Hoogeveen, J., Bierkens, M. F. P., van Beek, L. P. H., \& Debele, B. (2012). Water resources trends in Middle East and North Africa towards 2050. Hydrology and Earth System Sciences, 16, 3101-3014. doi:10.5194/hess-16-3101-2012

Ferreras-Romero, M., \& García-Rojas, A. M. (1995). Life-history patterns and spatial separation exhibited by the odonates from a Mediterranean inland catchment in southern Spain. Vie et Milieu, 45, 157-166. doi:10.1007/978-94-009-2397-3_44

Ferreras-Romero, M., \& Márquez-Rodríguez, J. (2014). Odonatos asociados a cursos estacionales de Sierra Morena (sur de España). Boletin de la Asociación Española de Entomologia, 38, 173-184.

Ferreras-Romero, M., Márquez-Rodríguez, J., \& Ruiz-García, A. (2009). Implications of anthropogenic disturbance factors on the Odonata assemblage in a Mediterranean fluvial system. International Journal of Odonatology, 12, 413-428. doi:10.1080/13887890.2009.9748354

Fox, J. W. (2013). The intermediate disturbance hypothesis should be abandoned. Trends in Ecology \& Evolution, 28, 86-92. doi:10.1016/j.tree.2012.08.014

Gasith, A. \& Resh, V. H. (1999). Streams in Mediterranean climate regions: abiotic influences and biotic responses to predictable seasonal events. Annual Review of Ecology and Systematics, 30, 51-81.

Gillman, L. N., \& Wright, S. D. (2006). The influence of productivity on the species richness of plants: a critical assessment. Ecology, 87, 1234-1243. doi:10.1890/0012-9658(2006)87[1234:tiopot]2.0.co;2

Hafiane, M., Hamzaoui, D., Attou, F., Bouchelouche, D., Arab, A., Alfarhan, A. H., \& Samraoui, B. (2016). Anthropogenic impacts and their influence on the spatial distribution of the Odonata of wadi El Harrach (North-Central Algeria). Revue d' Ecologie (Terre \& Vie), 71, 239-249.

Hawking, J. H., \& New, T. R. (1999). The distribution patterns of dragonflies (Insecta: Odonata) along the Kiewa River, Australia, and their relevance in conservation assessment. Hydrobiologia, 392, 249-260. doi:10.1023/ a: 1003510514937

Hershkovitz, Y., \& Gasith, A. (2013). Resistance, resilience, and community dynamics in mediterranean-climate streams. Hydrobiologia, 719, 59-75. doi:10.1007/s10750-012-1387-3

Hofmann, T. A., \& Mason, C. F. (2005). Habitat characteristics and the distribution of Odonata in a lowland river catchment in eastern England. Hydrobiologia, 539, 137-147. doi:10.1007/s10750-004-3916-1

Islam, S., \& Susskind, L. (2015). Understanding the water crisis in Africa and the Middle East: How can science inform policy and practice? Bulletin of the Atomic Scientists, 71, 39-49. doi:10.1177/0096340215571906

Karaouzas, I., Theodoropoulos, C., Vardakas, L., Kalogianni, E., \& Skoulikidis, N. Th. (2018). A review of the effects of pollution and water scarcity on the stream biota of an intermittent Mediterranean basin. River Research and Applications, 34, 291-299. doi:10.1002/rra.3254

Khelifa, R., Youcefi, A., Kahlerras, A., Alfarhan, A. H., Al-Rasheid, K. A. S., \& Samraoui, B. (2011). L'odonatofaune (Insecta : Odonata) du bassin de la Seybouse en Algerie : intérêt pour la biodiversité du Maghreb. Revue d'Ecologie (Terre \& Vie), 66, 55-66.

Lê, S., Josse, J., \& Husson, F. (2008). FactoMineR: An R package for multivariate analysis. Journal of Statistical Software, 25, 1-18. doi:10.18637/jss.v025.i01

Loock, M. M., Beukes, J. P., \& van Zyl, P. G. (2015). Conductivity as an indicator of surface water quality in the proximity of ferrochrome smelters in South Africa. Water SA, 41, 705-711. doi:10.4314/wsa.v41i5.14

Morghad, F., Samraoui, F., Touati, L., \& Samraoui, B. (2019). The times they are a changin': impact of land-use shift and climate warming on the odonate community of a Mediterranean stream over a 25 -year period. Vie et Milieu, 69, 25-33.

McPeek, M. A., \& Brown, J. M. (2000). Building regional species pool: diversification of the Enallagma damselflies in Eastern North America. Ecology, 81, 904-920. doi:10.2307/177166

Rahel, F. J., \& Olden, J. D. (2008). Assessing the effects of climate change on aquatic invasive species. Conservation Biology, 22, 521-533. doi:10.1111/j.1523-1739.2008.00950.x

R Development Core Team (2018). R: A language and environment for statistical computing. Vienna, Austria.

Remsburg, A. J., \& Turner, M. G. (2009). Aquatic and terrestrial drivers of dragonfly (Odonata) assemblages within and among north-temperate lakes. Journal of North American Benthological Society, 28, 44-56. doi:10.1899/08-004.1

Riservato, E., Boudot, J.-P., Ferreira, S., Jović, M., Kalkman, V. J., Schneider, W., Samraoui, B., \& Cuttelod, A. (2009). The status and distribution of dragonflies of the Mediterranean Basin. Gland, Switzerland: IUCN. doi:10.2305/iucn.ch.2009.18.en

Samraoui, B. (2009). Seasonal ecology of Algerian Lestidae (Odonata). International Journal of Odonatology, 12, 383394. doi:10.1080/13887890.2009.9748352 
Samraoui, B., Boudot, J.-P., Ferreira, S., Riservato, E., Jovic, M., Kalkman, V. J., \& Schneider, W. (2010). The status and distribution of dragonflies. In N. Garcia, A. Cuttelod, \& D. Abdul Malak (Eds.), The status and distribution of freshwater biodiversity in Northern Africa (pp. 51-70). Gland, Switzerland: IUCN.

Samraoui, B., Bouzid, S., Boulahbal, R., \& Corbet, P. S. (1998). Postponed reproductive maturation in upland refuges maintains life-cycle continuity during the hot, dry season in Algerian dragonflies (Anisoptera). International Journal of Odonatology, 1, 118-135. doi:10.1080/13887890.1998.9748100

Samraoui, B., \& Corbet, P.S. (2000a). The Odonata of Numidia. Part I: Status and distribution. International Journal of Odonatology, 3, 11-25. doi:10.1080/13887890.2000.9748133

Samraoui, B., \& Corbet, P.S. (2000b). The Odonata of Numidia. Part II: Seasonal ecology. International Journal of Odonatology, 3, 27-39. doi:10.1080/13887890.2000.9748134

Samraoui, B., \& Menai, R. (1999). A contribution to the study of Algerian Odonata. International Journal of Odonatology, 2, 145-165. doi:10.1080/13887890.1999.9748126

Samraoui, B., \& Samraoui, F. (2008). An ornithological survey of the wetlands of Algeria: Important Bird Areas, Ramsar sites and threatened species. Wildfowl, 58, 71-98.

Samways, M. J., McGeoch, M. A., \& New, T. R. (2010). Insect conservation: a handbook of approaches and methods. Oxford, UK: Oxford University Press.

Schoener, T. W. (1982). The controversy over interspecific competition. American Scientist, 70, 586-590.

Schridde, P., \& Suhling, F. (1994). Larval dragonfly communities in different habitats of a Mediterranean running water system. Advances in Odonatology, 6, 89-100.

Solimini, A. G., Tarallo, G. A., \& Carchini, G. (1997). Life history and species composition of the damselfly assemblage along the urban tract of a river in central Italy. Hydrobiologia, 356, 21-32. doi:10.1023/a:1003123129478

Statzner, B., Doledec, S., \& Hugueny, B. (2004). Biological trait composition of European streams invertebrate communities: assessing the effects of various trait filter types. Ecography, 27, 470-488. doi:10.1111/j.0906-7590.2004.03836.x

Steward, T. W., \& Downing, J. A. (2008). Macroinvertebrate communities and environmental conditions in recently constructed wetlands. Wetlands, 28, 141-150. doi:10.1672/06-130.1

Suhling, F. (1996). Interspecific competition and habitat selection by the riverine dragonfly Onychogomphus uncatus. Freshwater Biology, 35, 209-217. doi:10.1046/j.1365-2427.1996.00491.x

Suhling, F. (1999). Effects of fish on the microdistribution of different larval size groups of Onychogomphus uncatus (Odonata: Gomphidae). Archiv für Hydrobiologie, 144, 229-244. doi:10.1127/archiv-hydrobiol/144/1999/229

Suhling, F. (2001). Intraguild predation, activity patterns, growth and longitudinal distribution in running water odonate larvae. Archiv für Hydrobiologie, 151, 1-15. doi:10.1127/archiv-hydrobiol/151/2001/1

Ward, J. V., \& Voelz, N. J. (1998). Altitudinal distribution patterns of surface water and groundwater faunas. In G. Bretschko, \& J. Helešic (Eds.), Advances in River Bottom Ecology (pp. 135-142). Leiden, The Netherlands: Backhuys Publishers.

Weiher, E., \& Keddy, P. A. (1999). Ecological Assembly Rules: Perspectives, Advances, Retreats. Cambridge, UK: Cambridge University Press. doi:10.1017/cbo9780511542237

Wilkinson, D. M. (1999). The disturbing history of intermediate disturbance. Oikos, 84, 145-147. doi:10.2307/3546874

Yalles-Satha, A., \& Samraoui, B. (2017). Environmental factors influencing Odonata communities of three Mediterranean rivers: Kebir-East, Seybouse and Rhumel Wadis, Northeastern Algeria. Revue d'Ecologie (Terre \& Vie), 72, $314-329$. 